\title{
Effects of fishing technique on assessing species composition in aquatic systems in semi-arid Brazil
}

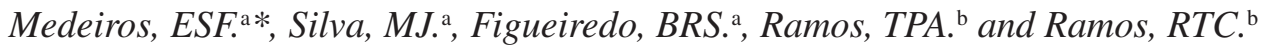 \\ ${ }^{a}$ Grupo de Ecologia de Rios do Semi-árido, Centro de Ciências Biológicas e Sociais Aplicadas, \\ Universidade Estadual da Paraíba - UEPB, \\ Campus V, CEP 58020-540, João Pessoa, PB, Brazil

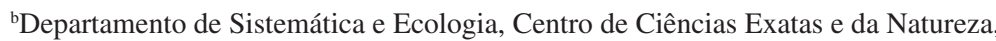 \\ Universidade Federal da Paraíba - UFPB, \\ CEP 58059-900, João Pessoa, PB, Brazil \\ *e-mail: elviomedeiros@uepb.edu.br
}

Received October 6, 2008 - Accepted November 11, 2008 - Distributed May 31, 2010

(With 4 figures)

\begin{abstract}
In most ecological field research, appropriate sampling is critical for the understanding of processes underlying fish populations and communities, and is even more important in heterogeneous environments such as the aquatic systems of the semi-arid region of Brazil. This study intends to make a contribution to the development of sampling programs and gear selection in aquatic systems of semi-arid Brazil by evaluating the effects of different fishing techniques on the assessment of richness and composition of the fish fauna in selected aquatic environments. Six sites were selected to represent typical artificial (reservoirs) and natural (intermittent streams) environments and four different types of sampling gear were applied to each site during four occasions. The present study shows that when selecting sampling techniques to be used in aquatic systems in semi-arid Brazil, one must consider the objectives of the study, e.g. ecological or taxonomic, in order to decide on inclusion of rare species in the sampling population. Also, the effect of the sampling gear on natural abundances of fish must be considered given that some sampling techniques are highly detrimental to fish population numbers.
\end{abstract}

Keywords: semi-arid, fish, richness, sampling technique, intermittent streams.

\section{Efeitos de diferentes artes de pesca na avaliação da composição de espécies em ambientes aquáticos do semiárido brasileiro}

\begin{abstract}
Resumo
Na maioria dos estudos ecológicos, uma amostragem representativa é crucial para o conhecimento dos processos que organizam populações e comunidades de peixes, principalmente em ambientes reconhecidamente heterogêneos como os ecossistemas aquáticos da região semiárida do Brasil. O presente estudo pretende contribuir para este conhecimento avaliando os efeitos de diferentes técnicas de captura de peixes na riqueza e composição das espécies amostradas em ambientes aquáticos do semiárido. Seis pontos de coleta foram selecionados, representando ambientes aquáticos artificiais (açudes) e naturais (rios intermitentes), onde quatro tipos de apetrechos de pesca foram empregados em quatro ocasiões. O presente estudo mostra que, ao selecionar técnicas de amostragem de peixes em ambientes aquáticos do semiárido brasileiro, dois fatores devem ser levados em consideração: primeiro, os objetivos do estudo, ecológicos ou taxonômicos, para se avaliar a importância da inclusão de espécies raras na população amostral; e segundo, os efeitos da técnica de amostragem na abundância natural de espécies, tendo em vista que algumas artes de pesca têm um efeito negativo nos números populacionais das espécies de peixes.
\end{abstract}

Palavras-chave: semiárido, peixes, riqueza de espécies, artes de pesca, rios intermitentes.

\section{Introduction}

Aquatic systems in semi-arid Brazil include three major groups of environments: intermittent streams and rivers (except for the perennial São Francisco River and artificially regulated rivers) (Maltchik and Medeiros, 2006a), natural shallow lakes (Maltchik et al., 1999), and artificial reservoirs (Medeiros et al., 2006). These systems are distinctive landscape features, comprising a range of associated sub-systems and existing as an 
ever-changing mosaic of dry/wet patches in the semiarid landscape of Brazil. Such aquatic environments are disturbance-dominated systems with the extremes of flooding and drying being drivers of important processes maintaining diversity (Maltchik and Florin, 2002). Recently, the importance of such variability as well as catchment- and local-level factors affecting habitat structure has also been recognized (Medeiros et al., 2008). Because the physical structure of the aquatic habitat is viewed as a framework for colonization by the aquatic fauna (e.g. Martin-Smith, 1998), the state of this living space will influence biotic structure and organization within aquatic systems (Mugodo et al., 2006).

In most ecological field research, appropriate sampling is critical for the understanding of processes underlying populations and communities, and even more important in traditionally heterogeneous environments, such as the aquatic systems of dry lands (Medeiros and Maltchik, 2001b; Medeiros and Arthington, 2008). In the semi-arid region of Brazil, a wide range of sampling strategies and gear types has been used in studies on ecological processes and diversity patterns. However, the unique physical and temporal characteristics of semi-ar- id aquatic systems of Brazil must be considered when designing a sampling program. Because these habitats change drastically over time, being either with high levels of water flow or as drying water bodies, as water levels fluctuate, fish distribution may change with habitat alterations (Medeiros et al., 2008). In such conditions, estimates of species composition and richness may be greatly affected.

In addition to that, the need for minimum impact on fish numbers is critical. During the dry period, for instance, shrinking pools represent the only habitat available in streams and rivers in semi-arid Brazil (Medeiros and Maltchik, 2000). If such pools are over-sampled, the removal of a large number of individuals may affect the structure of the community and lead to erroneous estimates in subsequent sampling occasions. From a conservation standpoint, natural pools in intermittent streams (temporary or semi-permanent) may act as refugia for fish and play an important role as breeding sites (Medeiros and Maltchik, 2000; Maltchik and Medeiros, 2006b), therefore, disturbance by over-sampling should be avoided.

For those reasons, one of the most important decisions in developing a sampling program for semi-arid

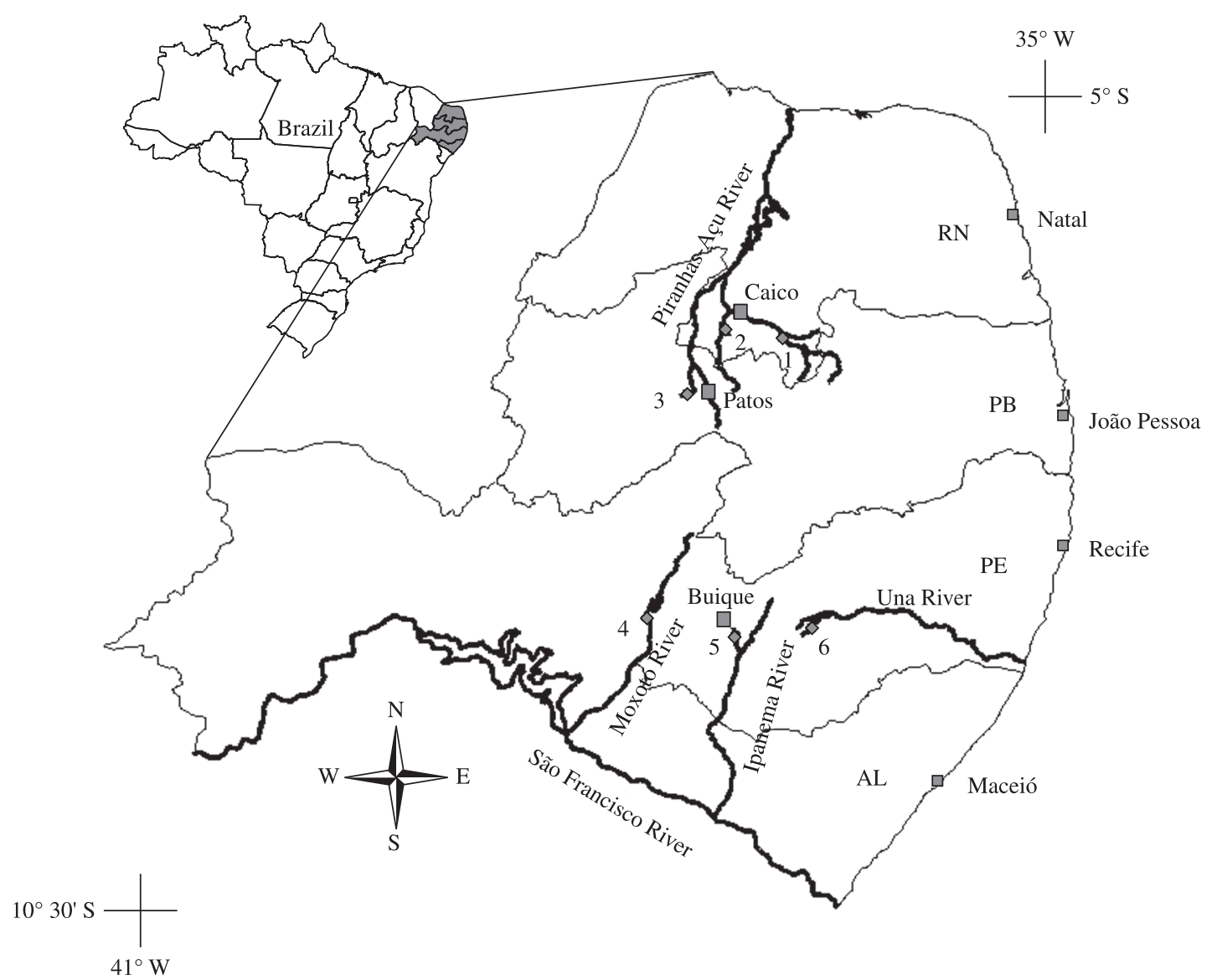

Figure 1. Study area showing the states of Rio Grande do Norte (RN), Paraíba (PB), Pernambuco (PE) and Alagoas (AL), major river systems and sampling sites in the semi-arid region of Brazil. Sites 1,2, and 4 are intermittent streams and sites 3,5 , and 6 are reservoirs. 
systems of Brazil is the gear selection. Gear selection should be based not only on requirements from data and specific objectives of the study (as proposed by Rozas and Minello, 1997), but also on their efficiency in sampling a wide variety of species with minimum impact to the community, and to the physical habitat. Many types of sampling gear and techniques have been used to collect fish in semi-arid systems of Brazil, such as beach seines, cast nets, gill nets, hand nets, etc (see review by Maltchik and Medeiros, 2006a, among others). Nevertheless, the collection of quantitative data appropriate for ecological studies on fish fauna composition and its variation remains a major challenge. This study intends to give a contribution to the development of sampling programs and gear selection in aquatic systems of the semi-arid region of Brazil by evaluating the effects of different fishing techniques on the assessment of richness and composition of the fauna in selected aquatic environments.

\section{Material and Methods}

\subsection{Study area}

This study was performed in two different areas of the Brazilian semi-arid region: Seridó/Borborema and Buíque/Vale do Ipojuca (as per Tabarelli and Silva, 2003) (Figure 1). These areas are classified as being of extreme biological importance and were identified as priority areas for biodiversity conservation in the Caatinga by Silva et al. (2003), because they present high diversity of species and are rich in endemisms. The Seridó area is located in southern Rio Grande do Norte (RN) and northern Paraíba (PB) between Patos and Caicó (Figure 1). Average annual temperature is $30.7{ }^{\circ} \mathrm{C}$, with the maximum monthly average in October $\left(31.0{ }^{\circ} \mathrm{C}\right)$ and the minimum average in February $\left(29.3{ }^{\circ} \mathrm{C}\right)$. Precipitation is concentrated between January and April, with 350 to $800 \mathrm{~mm}$ per annum and an annual average of $600 \mathrm{~mm}$ (Amorim et al., 2005). Altitude in Seridó reaches between 100 and $800 \mathrm{~m}$ (Governo do Estado da Paraíba, 1985). The Buíque area is located around the town of Buíque in central Pernambuco (PE) (Figure 1). Average annual temperature and precipitation are $25^{\circ} \mathrm{C}$ and $1095.9 \mathrm{~mm}$, respectively. Rainfall is concentrated between April and June. Altitude ranges between 800 and $1000 \mathrm{~m}$ (Rodal et al., 1998). The Seridó area is drained mostly by the Piranhas-Açu River basin, with the Seridó River as the main affluent, and the Buíque area is drained mostly by affluents of the São Francisco River (e.g. Moxotó and Ipanema rivers). In the state of Pernambuco, this study spanned further than the Buíque area with a sampling site at the headwaters of the Una River, which flows east to the Atlantic Ocean (Figure 1). Aquatic systems in the study areas are rich in habitat elements (littoral grass, aquatic macrophytes, overhanging and submerged vegetation and submerged wood debris) and in substrate com- position (mud, sand and cobbles) (see Medeiros et al., 2008 for further detail).

\subsection{Study design and data analysis}

Within each of the two study areas, three sites were selected to represent typical artificial (reservoirs) and natural temporary and semi-permanent environments (intermittent streams) (Figure 1). Sites consisted of stream reaches, usually 100 to $500 \mathrm{~m}$ long, and artificial reservoirs created from stream impoundment. Sampling was conducted during one year on four occasions during the wet (April and June 2006) and dry seasons (September and December 2006). Site 4 (Figure 1) was not sampled in April 2006.

On each sampling occasion and site, four different types of sampling gear were applied during day-light hours: a short beach seine net (4 m long, $1.5 \mathrm{~m}$ high and $5 \mathrm{~mm}$ mesh), a long beach seine net (20 m long, $2 \mathrm{~m}$ high and $12 \mathrm{~mm}$ mesh), one set of gill nets (30 m long and $1.5 \mathrm{~m}$ high equally divided into three $10 \mathrm{~m}$ panels of 35,45 and $55 \mathrm{~mm}$ meshes) and a cast net (2.4 $\mathrm{m}$ high and $12 \mathrm{~mm}$ mesh). Effort of capture was similar across sampling occasions and sites, and measured in hours (for the passive method), representing the number of hours of the gill nets in the water, or replicates (for active methods), representing the number of hauls (for seine nets) or the number of throws (for the cast net) performed. Hauls were similar across all sampling occasions and sites, being approx. $10 \mathrm{~m}$ long for the large seine net and 3-5 m long for the short seine net. Throws with the cast net were only taken into account when the net landed fully open in the water. Fish caught were fixed in $10 \%$ formalin in the field and later transferred to $75 \%$ ethanol and identified in the "Laboratório de Ictiologia" of "Departamento de Sistemática e Ecologia (Universidade Federal da Paraíba)". Voucher specimens are currently being deposited at the "Coleção Ictiológica da Universidade Federal da Paraíba (UFPB)". Fish were collected under License No. 032-DIFAP/IBAMA from 23 March 2006.

Values of richness and abundance standardized per unit effort of capture (number of fish captured was divided by the number of hours or replicates of each sampling technique on each sampling occasion and site) were compared using ANOVA. A factorial ANOVA (Zar, 1999) was performed on richness and abundance of fish standardized per unit effort of capture, with habitat type (river and reservoir), area (Seridó and Buíque) and sampling gear (short and long seine nets, gill net and cast net) as factors, to test for the presence of interaction among factors. In the absence of interaction and to locate possible sources of differences in the variable of interest (sampling technique), analysis of simple effects was performed with one-way ANOVA followed by post-hoc multiple comparisons using Tukey's HSD test (significance level of 0.05) (Sheridan and Lyndall, 2001). Simple regression and Pearson's correlation coefficient were used to evaluate the relationship between richness and abundance of fish caught for each sampling 
technique. Similarities in species composition among the four sampling techniques were summarized using Detrended Correspondence Analysis (DCA) (McCune and Mefford, 1999) of the standardized $\log _{10}(n+1)$ data (Sokal and Rohlf, 1969). To evaluate species composition associated with sampling techniques, a joint plot of the DCA solution and the species correlations with the axes $\left(r^{2}>0.2\right)$ was generated (McCune and Mefford, 1999), where the direction and length of vectors indicate the strength of correlation. All statistics were made after catches were standardized per effort of capture.

Because of the natural variations in fish fauna between natural (intermittent streams) and artificial (reservoirs) aquatic systems in semi-arid Brazil (Medeiros et al., 2006) and the reported high temporal variability in species composition between wet and dry seasons (Maltchik and Medeiros, 2001; Medeiros and Maltchik, 2001a, b), effects of fishing gear selectivity on species composition were not compared between sites and sampling occasions, as it would not be possible to ascertain whether differences in capture would be due to sampling gear or natural spatio-temporal variation in fish fauna.

\section{Results}

During the present study a total of 7769 fish representing 34 species and 12 families was captured. The family Characidae was the richest with 11 species, followed by Cichlidae (6 species) and Curimatidae (4 species). The most abundant species contributed to more than $10 \%$ of fish caught (Astyanax bimaculatus (Linnaeus, 1758), Geophagus brasiliensis (Quoy and Gaimard, 1824) and Oreochromis niloticus (Linnaeus, 1758)). These species were also the most common, being present in at least $65 \%$ of the sampling occasions and sites (Table 1). Even though Hoplias malabaricus (Bloch, 1794) contributed with less than $2 \%$ of the total catches, this species was among the most common ones, present in $65.2 \%$ of the sampling occasions and sites. Seine nets were the most efficient sampling techniques capturing $92.8 \%$ of the fish (after correction for catch per unit of effort) and 32 of the 34 species found. The short seine net caught an average $( \pm \mathrm{SD})$ of $44.3( \pm 86.2)$ individuals and $1.0( \pm 0.6)$ species per unit of effort and the long seine net caught $37.8( \pm 39.9)$ individuals and $1.6( \pm 1.4)$ species per unit of effort, whereas the cast net caught $4.2( \pm 5.0)$ individuals and $0.5( \pm 0.4)$ species per unit of effort and the gill net caught $2.2( \pm 3.5)$ individuals and $0.4( \pm 0.3)$ species per unit of effort.

Factorial ANOVA showed that differences in average richness corrected for effort of capture were significant only for habitats $(1.2 \pm 1.1$ species for river sites and $0.6 \pm 0.6$ species for reservoir sites) (ANOVA $F=20.1$, $\mathrm{df}=1 ; 76, \mathrm{p}=0.0001$ ), and sampling techniques (ANOVA $\mathrm{F}=11.6, \mathrm{df}=3 ; 76, \mathrm{p}=0.0001$ ) (Figure 2a). Furthermore, interaction among all three factors (habitat, area and sampling gear) was not significant (ANOVA $F=0.6$, $\mathrm{df}=3 ; 76, \mathrm{p}=0.593)$. On the other hand, differences in abundance corrected for effort of capture were significant only for sampling techniques (ANOVA $F=19.0$, $\mathrm{df}=3 ; 76, \mathrm{p}=0.0001$ ) (Figure $2 \mathrm{~b}$ ). Interaction among all three factors was also not significant for abundance (ANOVA F $=0.2$, df $=3 ; 76, p=0.897$ ). Since the influence of sampling gear in richness and abundance did not depend on the area studied or habitat type (showed by the absence of significant interaction), one-way ANOVA post-hoc tests could be performed on sampling technique to evaluate the significance of differences. Average richness of fish caught was significantly different only between the long seine net and the cast net (Tukey HSD $\mathrm{p}=0.0001$ ) and the long seine net and the gill net (Tukey HSD $p=0.0001$ ) (Figure 2a). With regard to the average abundance of fish caught, differences were significant between the short seine net and the cast net (Tukey HSD $p=0.026$ ) and the short seine net and the gill net (Tukey HSD $p=0.018$ ) (Figure 2b). Simple regression analysis on richness and abundance showed a strong correlation between the number of fish captured and the number of species (Figure 3).

Ordination by DCA of species abundances after correction for effort of capture pooled for sampling occasions and sites (Figure 4) summarizes the similarities in
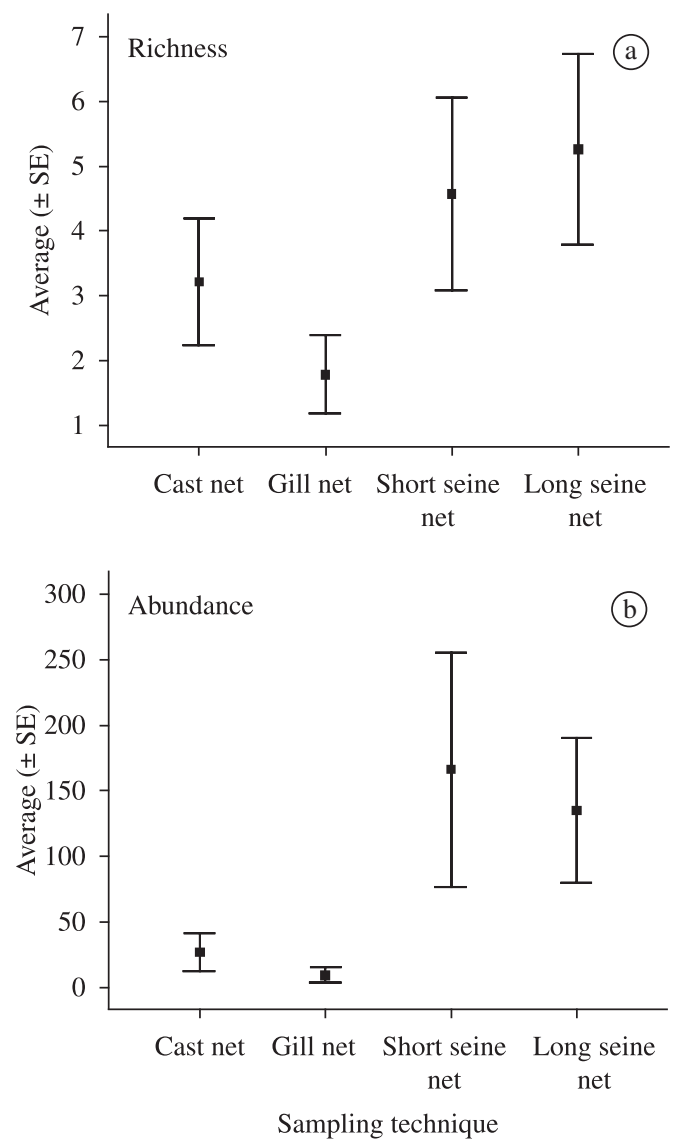

Figure 2. Average richness and abundance of fish (corrected for effort of capture) captured by different sampling techniques in aquatic systems of the semi-arid region of Brazil. 


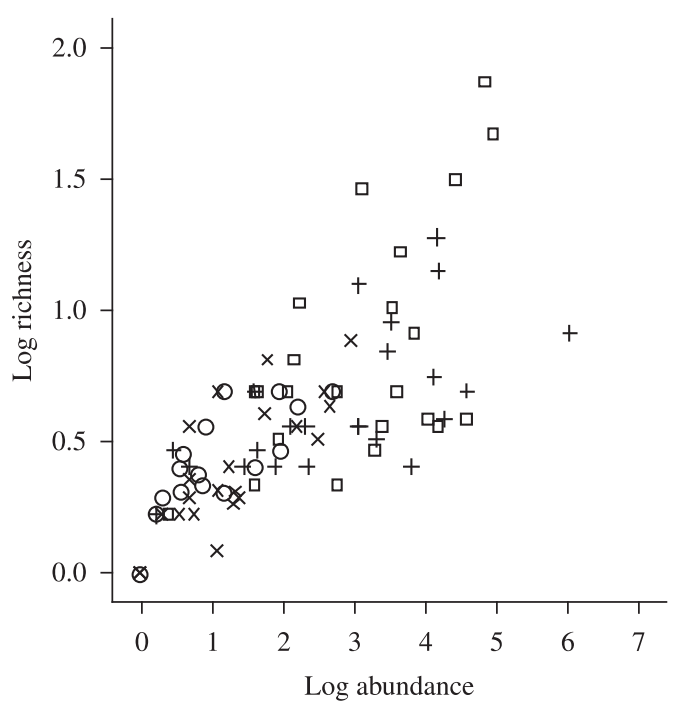

Figure 3. Regression between abundance and richness of species for each sampling technique. $\times=$ cast net $\left(r^{2}=0.789\right.$, $\mathrm{p}=0.0001), \circ=$ gill net $\left(\mathrm{r}^{2}=0.854, \mathrm{p}=0.0001\right),+=$ short seine net $\left(\mathrm{r}^{2}=0.634, \mathrm{p}=0.001\right)$ and $\square=$ long seine net $\left(r^{2}=0.585, p=0.002\right)$. Data is $\log _{10}(x+1)$ transformed.

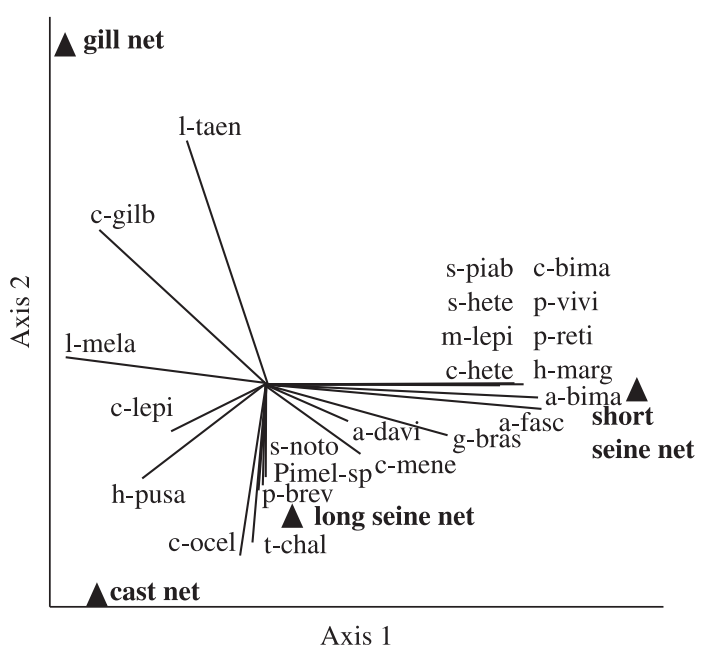

Figure 4. Joint plot of DCA bi-dimensional solution for fish species composition across sampling techniques and fish species correlated $\left(r^{2}>0.2\right)$ with sampling techniques in ordination space (denoted by vectors). The direction and length of vectors indicate strength of correlation. See Table 1 for full names of fish species.

composition of species of fish caught for the sampling techniques. The first two axes of DCA accounted for $77.3 \%$ of the total variation in the data set, with $47.2 \%$ of the variation explained by the first axis alone. Ordination shows a higher segregation of the gill net in relation to the other sampling techniques, whereas the cast net and the long seine net lay closer to each other, representing similar composition of species captured. Fish species correlated $\left(\mathrm{r}^{2}>0.2\right)$ with sampling techniques (denoted by vectors in Figure 4 ) indicate that the abundance-based similarities corroborate results from ANOVA showing a higher number of species positively associated to Axis 1, and therefore, the short seine net. A small number of species positively correlated with Axis 2 is also evident, indicating a lower diversity of species for the gill net. The cast net and long seine net, sampled a moderately diverse, yet different, portion of the fish fauna.

\section{Discussion}

The total number of species found in the present study is in accordance with other studies in the semi-arid region of Brazil (e.g. Medeiros and Maltchik, 2001a; Rosa et al., 2003; Medeiros et al., 2006), indicating that the sampling gear chosen is capable of taking representative samples of the fish fauna in the study habitats. The seine nets were clearly more efficient both in number of individuals and in number of species caught, with a greater number of individuals and species caught in comparison with the cast and gill nets. Given the high correlation between abundance and richness, it is evident that these techniques are more efficient due to their capacity of catching a greater number of individuals per unit of effort, when compared to the cast and gill nets.

Ribeiro and Zuanon (2006) observed for igarapés in central Amazon that an active method of fish capture was more efficient than a passive one. This was justified by the high rates of escape associated with the passive method. In the present study, escape may have been an important factor given that gill nets keep fish trapped for relatively long periods, which not only increases their escape probability, but may also warn other fish around and attract predators, such as Hoplias malabaricus. Nevertheless, other factors must be considered. Gill nets are highly selective, targeting larger fish that inhabit the superficial portion of the water column. Furthermore, gill nets have a lower effectiveness in the shallower littoral margins where fish frequently forage (Burks et al., 2002) and where most habitat structures are present (Medeiros et al., 2008). Even though Borgstrom (1992) suggested that habitat interactions could affect efficiency of gill nets in European lakes, data from the present study showed that gill net efficiency was not significantly different between river and reservoir sites, which differ in habitat structure (Medeiros et al., 2008).

An important factor associated with gill nets is the mesh size. Even though in the present study three different mesh sizes were used, catches were low. Studies show that gill nets are highly size-selective, with capture concentrated in a few range of lengths, retaining fish with lengths no more than $20 \%$ of the optimum length (Rojo-Vázquez et al., 2001). Furthermore, Rojo-Vázquez et al. (2001) report an $80 \%$ overlap of range of fish length 
Table 1. Fish species captured (\% abundance and N) and Frequency (across sampling occasions and sites) during the study period and efficiency of capture $(\%)$ of four sampling techniques in aquatic systems in semi-arid Brazil. * indicates species unique to a sampling gear and $\$$ indicates species not caught by seine nets.

\begin{tabular}{|c|c|c|c|c|c|c|}
\hline Species & $\begin{array}{c}\% \mathrm{~N} \\
(\mathrm{n}=7769)\end{array}$ & $\begin{array}{c}\text { Freq } \\
(\mathrm{n}=\mathbf{2 3})\end{array}$ & $\begin{array}{c}\text { Long } \\
\text { seine net }\end{array}$ & $\begin{array}{c}\text { Short } \\
\text { seine net }\end{array}$ & $\begin{array}{l}\text { Gill } \\
\text { net }\end{array}$ & $\begin{array}{c}\text { Cast } \\
\text { net }\end{array}$ \\
\hline Astyanax bimaculatus (Linnaeus, 1758) & 23.84 & 19 & 8.41 & 14.86 & 0.22 & 0.57 \\
\hline Geophagus brasiliensis (Quoy and Gaimard, 1824) & 12.85 & 15 & 7.43 & 9.77 & 0.03 & 0.41 \\
\hline Oreochromis niloticus (Linnaeus, 1758) & 10.12 & 16 & 6.27 & 1.46 & 0.03 & 0.66 \\
\hline Poecilia vivipara Bloch and Schneider, 1801 & 9.82 & 11 & 0.76 & 5.87 & 0.05 & 0.00 \\
\hline Characidium bimaculatum Fowler, 1941 & 8.92 & 5 & 1.11 & 6.92 & 0.00 & 0.00 \\
\hline Parachromis managuensis (Günther, 1867) & 7.00 & 4 & 4.74 & 0.33 & 0.02 & 0.17 \\
\hline Poecilia reticulata Peters, 1859 & 3.89 & 5 & 0.50 & 6.43 & 0.00 & 0.00 \\
\hline Prochilodus brevis Steindachner, 1874 & 3.46 & 10 & 3.38 & 0.05 & 0.06 & 0.53 \\
\hline Serrapinnus heterodon (Eigenmann, 1915) & 3.41 & 8 & 0.02 & 2.35 & 0.08 & 0.00 \\
\hline Steindachnerina notonota (Miranda-Ribeiro, 1937) & 2.64 & 4 & 2.91 & 0.02 & 0.00 & 0.36 \\
\hline Triportheus signatus (Garman, 1890) & 2.63 & 6 & 2.55 & 0.04 & 0.38 & 0.57 \\
\hline Cichlasoma orientale Kullander, 1983 & 1.75 & 7 & 1.22 & 0.10 & 0.17 & 0.12 \\
\hline Cyphocarax gilbert (Quoy and Gaimard, 1824) & 1.67 & 2 & 0.58 & 0.01 & 0.90 & 0.15 \\
\hline Tetragonopterus chalceus Spix and Agassiz, 1829 & 1.65 & 2 & 0.92 & 0.03 & 0.00 & 0.41 \\
\hline Hoplias malabaricus (Bloch, 1794) & 1.33 & 15 & 0.61 & 0.20 & 0.23 & 0.10 \\
\hline Astyanax fasciatus (Cuvier, 1819) & 1.03 & 10 & 0.26 & 0.37 & 0.00 & 0.04 \\
\hline Serrapinnus piaba (Lütken, 1875)* & 0.88 & 1 & 0.00 & 0.67 & 0.00 & 0.00 \\
\hline Cichla ocellaris Schneider, 1801 & 0.86 & 5 & 0.48 & 0.03 & 0.02 & 0.28 \\
\hline Hypostomus pusarum (Starks, 1913) & 0.75 & 4 & 0.18 & 0.06 & 0.15 & 0.13 \\
\hline Moenkhausia lepidura (Kner, 1858) * & 0.41 & 2 & 0.00 & 0.31 & 0.00 & 0.00 \\
\hline Crenicichla menezesi Ploeg, 1991 & 0.32 & 5 & 0.18 & 0.08 & 0.01 & 0.02 \\
\hline $\begin{array}{l}\text { Curimatella lepidura } \\
\text { (Eigenmann and Eigenmann, 1889) }\end{array}$ & 0.26 & 2 & 0.04 & 0.02 & 0.05 & 0.10 \\
\hline Leporinus piau Fowler, 1941 & 0.17 & 8 & 0.01 & 0.03 & 0.04 & 0.05 \\
\hline Apareiodon davisi Fowler, 1941 & 0.12 & 2 & 0.08 & 0.03 & 0.00 & 0.00 \\
\hline Hemigrammus marginatus Ellis, $1911 *$ & 0.06 & 2 & 0.00 & 0.05 & 0.00 & 0.00 \\
\hline Pimelodella sp. & 0.05 & 1 & 0.00 & 0.01 & 0.00 & 0.04 \\
\hline Colossoma macropomum (Cuvier, 1818) * & 0.03 & 1 & 0.02 & 0.00 & 0.00 & 0.00 \\
\hline Leporinus melanopleura Günther, $1864 \ddagger$ & 0.03 & 1 & 0.00 & 0.00 & 0.01 & 0.01 \\
\hline Aspidoras rochai Lhering, $1907 *$ & 0.01 & 1 & 0.02 & 0.00 & 0.00 & 0.00 \\
\hline Compsura heterura Eigenmann, $1915 *$ & 0.01 & 1 & 0.00 & 0.01 & 0.00 & 0.00 \\
\hline Leporinus taeniatus Fowler, $1941 * \ddagger$ & 0.01 & 1 & 0.00 & 0.00 & 0.01 & 0.00 \\
\hline Moenkhausia costae (Steindachner, 1907) * & 0.01 & 1 & 0.02 & 0.00 & 0.00 & 0.00 \\
\hline $\begin{array}{l}\text { Psectrogaster rhomboides } \\
\text { Eigenmann and Eigenmann, } 1889 *\end{array}$ & 0.01 & 1 & 0.02 & 0.00 & 0.00 & 0.00 \\
\hline Lithoxancistrus genisetiger (Fowler, 1941) * & 0.01 & 1 & 0.02 & 0.00 & 0.00 & 0.00 \\
\hline $\begin{array}{c}\text { Total species } \\
\end{array}$ & \multicolumn{2}{|c|}{34} & 27 & 27 & 18 & 19 \\
\hline
\end{tabular}

caught for gill nets, even though they used nets with different mesh.

The present study corroborates other studies in semi-arid Brazil, showing that stream habitats will have a greater richness of fish than reservoir sites (Medeiros et al., 2006). Medeiros et al. (2006) suggest that such differences may be associated with contrasting habitat characteristics between streams and reservoirs. Studies demonstrate that submerged physical obstructions (e.g. rocks, macrophytes, branches) interfere with sampling techniques such as seine nets, preventing them from passing through the entire water column (Parsley et al., 1989; Pierce et al., 1990).

Despite the higher richness in stream sites found in the present study and the reported differences in habitat structure between river and reservoirs (Medeiros et al., 2008), fishing techniques were not influenced by habitat type or the area studied. This is an important result show- 
ing that the sampling gear used is not affected by local environmental factors, such as habitat type, or regional differences in fish species richness. On the other hand, the composition of species varied considerably across the sampling gear used. The most different sampling techniques were the short seine net and the gill net. Not surprisingly these two techniques target different portions of the fish populations (small littoral fish species and individuals versus large species/individuals from the open water) (Parsley et al., 1989). For example, all four species captured exclusively by the short seine net are small species that grow to a maximum Standard Length of 4.5 to $8.0 \mathrm{~cm}$ (Reis et al., 2003).

The long seine net and the cast net had more similar composition of species caught. Given their depth limitations and mesh sizes, these sampling techniques focus mostly on small- to medium-sized fish inhabiting relatively shallow littoral areas (Pierce et al., 1990; Emmanuel et al., 2008), in the present study between $50 \mathrm{~cm}$ and $1.2 \mathrm{~m}$ deep. Despite the fact that the cast net captured a fewer number of fish individuals compared to the seine nets, both seine and cast nets shared a considerable number of species.

In conclusion, the present study shows that two major aspects must be considered when organizing a sampling program for aquatic systems in semi-arid Brazil. The first one is related to the objectives of the study, that is, if samples are aimed at collecting fish for ecological studies that focus on variations in community richness and composition (when rare species are not as important), then seine nets are efficient sampling techniques. However, if the study is intended for the sampling of species for the production of species lists, taxonomic surveys or Rapid Assessment Programs, a wider range of sampling gear should be used to ensure that the least frequent and abundant species are also taken into account. The second aspect that must be considered when planning a sampling scheme is the effect of the sampling gear on natural abundances of fish. Techniques such as the short seine net used in the present study, although very efficient, are highly detrimental to fish population numbers. Thus, such a technique should be used with caution and after conscientious planning. Alternatively, the long seine net and the cast net used in the present study tended to catch less individuals per unit of effort, but were efficient in catching a representative sample of the fish fauna.

Acknowledgements - The authors are grateful to Virginia Diniz (Universidade Federal da Paraíba) for fieldwork assistance and to $\mathrm{CNPq} / \mathrm{UEPB} / \mathrm{DCR}$ for the scholarship granted to Elvio Medeiros (350082/2006-5). This research was supported by UEPB/FAPESQ (68.0006/2006.0) and Projeto de Pesquisa em Biodiversidade do Semi-árido (PPBio Semi-árido).

\section{References}

AMORIM, IL., SAMPAIO, EVSB. and ARAÚJO, EDL., 2005. Flora e estrutura da vegetação arbustivo-arbórea de uma área de caatinga do Seridó, RN, Brasil. Acta Botanica Brasilica, vol. 19 , no. 3, p. 615-623.

BORGSTROM, R., 1992. Effect of population density on gillnet catchability in four allopatric populations of brown trout (Salmo trutta). Canadian Journal of Fisheries and Aquatic Sciences, vol. 49, no. 8, p. 1539-1545.

BURKS, RL., LODGE, DM., JEPPESEN, E. and LAURIDSEN, TL., 2002. Diel horizontal migration of zooplankton: costs and benefits of inhabiting the littoral. Freshwater Biology, vol. 47, no. 3, p. 343-365.

EMMANUEL, BE., CHUKWU, LO. and AZEEZ, LO., 2008. Cast net design characteristics, catch composition and selectivity in tropical open lagoon. African Journal of Biotechnology, vol. 7, no. 12, p. 2081-2089.

GOVERNO DO ESTADO DA PARAÍBA. 1985. Atlas Geografico do Estado da Paraíba. João Pessoa: Grafset. 99 p.

MALTCHIK, L., COSTA, MAJ. and DUARTE, MDC., 1999. Inventory of Brazilian semi-arid shallow lakes. Anais da Academia Brasileira de Ciências, vol. 71, no. 4-I, p. 801-808.

MALTCHIK, L. and FLORIN, M., 2002. Perspectives of hydrological disturbance as the driving force of Brazilian semiarid stream ecosystems. Acta Limnologica Brasiliensia, vol. 14 , no. 3 , p. $35-41$.

MALTCHIK, L. and MEDEIROS, ESF., 2001. Does hydrological stability influence biodiversity and community stability? A theoretical model for lotic ecosystems from the Brazilian semiarid region. Journal of the Brazilian Association for the Advancement of Science, vol. 53, p. 44-48.

MALTCHIK, L. and MEDEIROS, ESF., 2006a. Conservation importance of semi-arid streams in north-eastern Brazil: implications of hydrological disturbance and species diversity. Aquatic Conservation: Marine and Freshwater Ecosystems, vol. 16, no. 7, p. 665-677.

,2006b. Diversidade, estabilidade e atividade reprodutiva de peixes em uma poça fluvial permanente no leito de um riacho efêmero, Riacho Avelós, Paraíba, Brasil. Revista de Biologia e Ciências da Terra, vol. Supl. Especial, no. 1, p. 20-28.

McCUNE, B. and MEFFORD, MJ. 1999. PC-ORD. Multivariate Analysis of Ecological Data. Version 4.27. MjM Software Design, Gleneden Beach, Oregon, U.S.A.

MEDEIROS, ESF. and ARTHINGTON, AH., 2008. Diel variation in food intake and diet composition of three native fish species in floodplain lagoons of the Macintyre River, Australia. Journal of Fish Biology, vol.73, no. 4, p. 1024-1032.

MEDEIROS, ESF. and MALTCHIK, L., 2000. Influence of hydrological disturbance on reproduction of a fish community in an intermittent stream from Brazilian semiarid region. Verhandlungen der Internationalen Vereinigung für theoretische und Angewandte Limnologie, vol. 27, p. 906-911.

, 2001a. Diversity and stability of fishes (Teleostei) in a temporary river of the Brazilian semiarid region. Iheringia, Série Zoologia, vol. 90, p. 157-166.

2001b. Fish assemblage stability in an intermittently flowing stream from the Brazilian semiarid region. Austral Ecology, vol. 26, no. 2, p. 156-164.

MEDEIROS, ESF., RAMOS, RTC., RAMOS, TPA. and SILVA, MJ., 2006. Spatial variation in reservoir fish assemblages along 
a semi-arid intermittent river, Curimataú River, northeastern Brazil. Revista de Biologia e Ciências da Terra, vol. Supl. Especial, no. 1, p. 29-39.

MEDEIROS, ESF., SILVA, MJ. and RAMOS, RTC., 2008. Application of catchment- and local-scale variables for aquatic habitat characterization and assessment in the Brazilian semi-arid region. Neotropical Biology and Conservation, vol. 3, no. 1, p. 13-20.

PARSLEY, JJ., PALMER, DE. and BURKHARDT, RW., 1989. Variation in capture efficiency of a beach seine for small fishes. North American Journal of Fisheries Management, vol. 9, no. 2, p. 239-244.

PIERCE, CL., RASMUSSEN, JB. and LEGGETT, WC., 1990. Sampling littoral fish with a seine: corrections for variable capture efficiency. Canadian Journal of Fisheries and Aquatic Sciences, vol. 47, no. 5, p. 1004-1010.

REIS, RE., KULLANDER, SO. and FERRARIS Jr., CJ., 2003. Check List of the Freshwater Fishes of South and Central America (CLOFFSCA). Porto Alegre: EDIPUCRS.

RIBEIRO, OM. and ZUANON, J., 2006. Comparação da eficiência de dois métodos de coleta de peixes em igarapés de terra firme da Amazônia Central. Acta Amazonica, vol. 36, no. 3, p. 389-394.

RODAL, MJN., ANDRADE, KVA., SALES, MF. and GOMES, APS., 1998. Fitossociologia do componente lenhoso de um refúgio vegetacional no município de Buique, Pernambuco. Revista Brasileira de Biologia = Brazilian Journal of Biology, vol. 58 , no. 3 , p. $517-526$.

ROJO-VÁZQUEZ, JA., ARREGUÍN-SÁNCHEZ, F. and GODÍNEZ-DOMÍNGUEZ, E., 2001. Fishing power, efficiency and selection of gillnets for the shortfin grunt (Microlepidotus brevipinnis Steindachner, 1869), in the southern coast of Jalisco, Mexico. Revista de Biología Marina y Oceanografía, vol. 36, no. 1, p. 9-14.

ROSA, RS., MENEZES, NA., BRITSKI, HA., COSTA, WJEM. and GROTH, F., 2003. Diversidade, padrões de distribuição e conservação dos peixes da Caatinga. In LEAL, IR., SILVA, JMC. and TABARELLI, M. (Eds.). Ecologia e conservação da Caatinga. Recife: EDUFPE. p. 135-181.

ROZAS, LP. and MINELLO, TJ., 1997. Estimating densities of small fishes and decapod crustaceans in shallow estuarine habitats: a review of sampling design with focus on gear selection. Estuaries, vol. 20, no. 1, p. 199-213.

SHERIDAN, JC. and LYNDALL, GS., 2001. SPSS: analysis without anguish. Version 10.0 for Windows. Australia: John Wiley \& Sons Australia. 266 p.

SILVA, JMC., TABARELLI, M., FONSECA, MTD. and LINS, LV., 2003. Biodiversidade da Caatinga: áreas e ações prioritárias para a conservação. Brasília: Ministério do Meio Ambiente. p. 382.

SOKAL, RR. and ROHLF, FJ., 1969. Biometry: the principles and practice of statistics in biological research. San Francisco: W.H. Freeman. 776 p.

TABARELLI, M. and SILVA, JMC., 2003. Áreas e ações prioritárias para a conservação da biodiversidade da Caatinga. In LEAL, IR., SILVA, JMC. and TABARELLI, M. (Eds.). Ecologia e conservação da Caatinga. Recife: EDUFPE. p. 777-796.

ZAR, JH., 1999. Biostatistical analysis. New Jersey: Prentice Hall. 663 p. 